\title{
SECOND REPORT ON \\ THE ORGANIZATION OF \\ PHARMACOLOGY IN GREAT BRITAIN
}

\author{
Y.S. BAKHLE \\ Department of Pharmacology, \\ Institute of Basic Medical Sciences, Royal College of Surgeons, London WC2A 3PN
}

D.W. STRAUGHAN

Department of Pharmacology, The School of Pharmacy, London WC1N 1AX

R.A. WEBSTER

Department of Pharmacology, University College, London WC1E 6BT

1 A questionnaire was sent to 150 departments employing pharmacologists including all those academic departments teaching pharmacology, in Great Britain and Northern Ireland, and all industrial firms and research institutes engaged in pharmacological (27) and toxicological (38) work. All questionnaires were completed. The returns refer to the situation on 1 st January 1972.

2 There were 1,104 pharmacologists, of whom 652 were established staff, 383 were research staff and students, and 29 visiting workers. Of the staff in established posts, 192 were in medical schools, 81 in other university departments, 75 in other non-university departments and 28 in toxicology departments. Forty pharmacologists were established in other research units.

3 Since 1964, 11 B.Sc. (Pharmacology) courses have been started. In 1971-72 there were 69 students in the final year of all B.Sc. Pharmacology courses. By 1974-75, 134 students are expected in the final year of these courses.

4 Of 413 students specializing in pharmacology who graduated in 1971, 74\% had taken a pharmacy qualification. Overall, $26 \%$ continued in academic courses, $11 \%$ went into industry, $56 \%$ into hospital or retail pharmacy. Only $1 \%$ were unemployed.

5 Of 68 students completing postgraduate courses in pharmacology in 1971, 20\% went into university teaching, $26 \%$ into industry and only $1 \%$ were unemployed. At present there are 260 students in postgraduate training in pharmacology departments.

6 During 1970 and 1971 appointments exceeded losses in all sections giving an overall annual gain of 58.5. The total demand was estimated at 73 per year over this time. The predicted size of pharmacology departments in 1974-75 could lead to a maximum annual demand of 95 per year for these next three years.

7 Up to January 1972, the supply of, and demand for pharmacologists seems to have been near balance from the unemployment and vacancy rates reported.

However, in 1971, the supply of pharmacologists exceeded significantly the identifiable demand from pharmacology and toxicology departments. Thus there was a considerable demand from unknown employers. In the future there will be a considerable increase in the supply of specialist pharmacologists. We cannot predict if this will be balanced by demand in the absence of information about the growth in demand from the unknown employers.

8 Taking the number of professors as an index of academic status, pharmacology has improved its standing, especially in the non-medical school departments. Now there are 40 professors in 51 departments compared with 25 in 42 departments in 1964.

9 Overall, the composition of departments has not changed much since 1964. Academic departments still draw on each other for their pharmacologists whereas industrial departments draw equally from other industrial departments and academic departments. The total proportion of medically qualified pharmacologists has fallen to $14 \%$ (from $25 \%$ in 1964) and these pharmacologists are still concentrated heavily in medical school departments. In industrial departments, only $3 \%$ have a medical qualification. 
10 From the replies of 94 out of 410 recent graduates specializing in pharmacology, the courses are in general interesting and effective. However, both students and employers considered that not enough statistics and mathematics as applied to pharmacology were taught. Of the respondents, $84 \%$ also wanted more teaching on the clinical use of drugs.

The first survey of the teaching and employment of pharmacologists in Britain was organized on behalf of the British Pharmacological Society in 1964 (Bakhle \& Paton, 1966). In conducting a second survey in 1971 , there were two main objectives. Firstly, the Society's membership had doubled and a realistic estimate of the growth of pharmacology was considered desirable; secondly, to examine the employment prospects of all graduates produced by the specialist pharmacology courses.

A questionnaire, closely modelled on the previous one, was sent out in March, 1972, to all academic departments (51) in Great Britain and Ireland in which pharmacology was taught (see note in Table 8) all known industrial departments of pharmacology (27) and toxicology (38) and to research institutes (34). A different questionnaire was sent to recent graduates in pharmacology asking chiefly for their opinions of the pharmacology courses they had recently taken.

Our returns should provide a reasonably complete coverage of the production of pharmacologists. We tried with a little success to cover more employment possibilities than the previous report in order to reach the trained pharmacologists employed in 'non-pharmacological' jobs. We hoped that the information from the recent graduates would also help in this respect.

A survey on the organization of clinical pharmacology in the United Kingdom has been completed recently by Smith (1974).

\section{General organization of pharmacology}

\section{Numbers and distribution}

All the 1,104 people employed in pharmacology have been divided into three groups; academic, industrial and other units (Table 1). The academic pharmacologists comprise those at medical schools, other university departments and nonuniversity departments. This last category refers to polytechnics and colleges of advanced technology (CATS) most of which were not included in the previous survey. The industrial section consists of research and development (R \& D) departments, with a separate entry for pharmacologists (defined by training, experience or function) in toxicology departments. The other units are, as before, a varied collection of research institutes and units

Table 1 Total numbers of pharmacologists

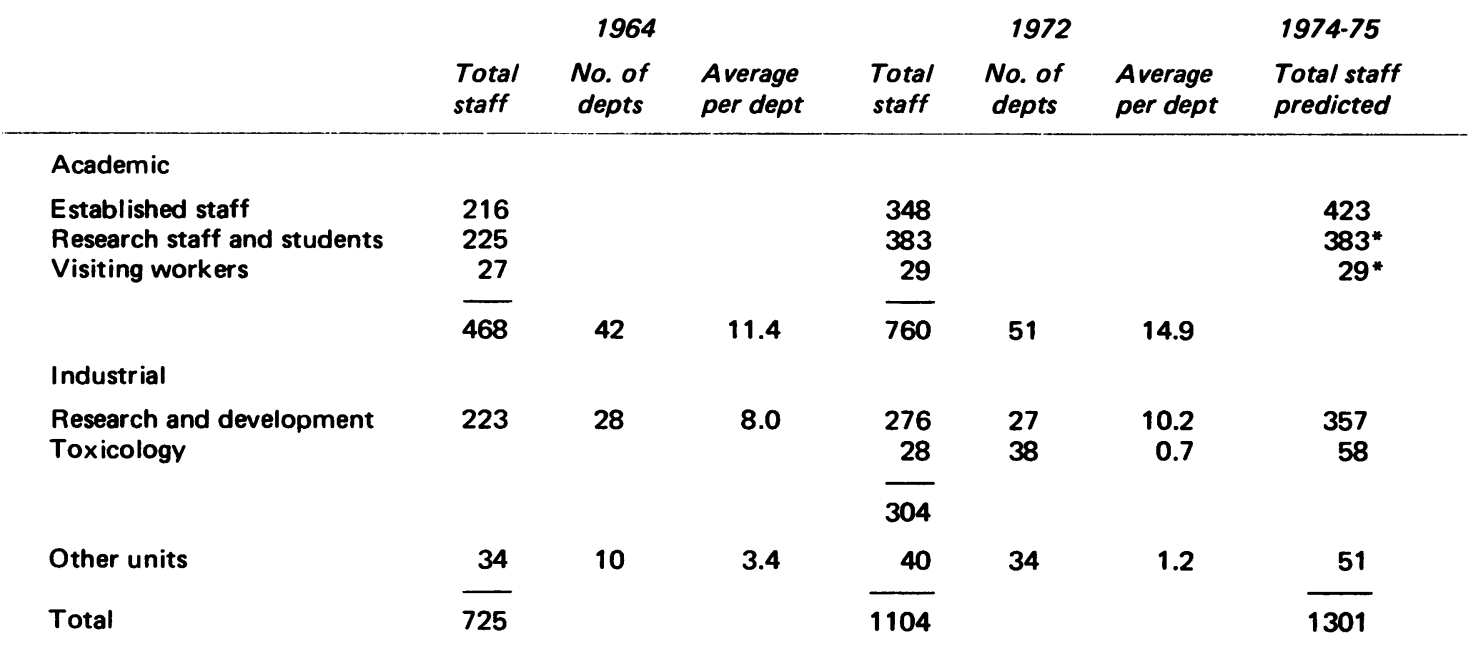

* We have assumed no increase in these categories from January 1972. 
and provide a group with the least secure definition as pharmacologists.

Academic pharmacologists, totalling 760 , comprise the majority $(69 \%)$ of the profession. This sector has grown from 468 since the last survey in 1964 when they formed $65 \%$ of all pharmacologists. There are now more departments of pharmacology ( 51 vs 42$)$ and the departments themselves are bigger (14.9 per department vs 11.4). The total number of pharmacologists in the industrial sector (including toxicology) has also increased in the last seven years from 223 to 304 though its share of the total remains much the same. The number of industrial $R \& D$ departments has decreased from 28 to 27 . Although we made a special effort to improve the recovery of pharmacologists from the variety of 'other units', surveying many more units than in 1964, the yield was only marginally better and these pharmacologists still provide problems in classification and analysis.

\section{Production of pharmacologists}

The 51 academic departments teach pharmacology to a variety of undergraduate students in medicine, pharmacy, dentistry, veterinary science, and biological science. Only 12 departments provide an undergraduate course specializing in pharmacology to Honours B.Sc. level. A further 10 provide such an intercalated course for medical or veterinary students and a further 15 departments provide an opportunity for pharmacy students to specialize in pharmacology in their final year. We have concentrated on the specialist graduates (and post- graduates) because they seemed more likely, by virtue of their training, to seek employment as pharmacologists. Further, more detailed information of these specialist graduates was available from teaching departments.

During 1971-72 there were 470 specialist students in their final year and their distribution between the different courses is shown in Table 2 , which also gives predicted student numbers (final year students only) for 1974-75. All the courses are to be expanded but the largest proportional increase predicted is in the B.Sc. (Pharmacology) students, whose output will be doubled by 1974-75. The predicted increase in specialists from pharmacy schools is also substantial (43\% over the 1971-72 numbers) and may be compared with an overall growth in pharmacy students of $9 \%$ over the last few years. It should be noted that, at present, only a quarter of these specialist pharmacy students take up pharmacology employment.

\section{Disposition of specialist graduates}

Where do the specialist students go after graduating? The answer for one year's output provided by the teaching departments is given in Table 3. In 1971 , a total of 413 students completed specialist undergraduate courses. Over half went into pharmacy and only about $10 \%$ entered industry, but apparently not all of these went into R \& D departments. A considerable proportion of the students went on to further undergraduate courses and these were mainly medical students who had taken the intercalated B.Sc. before going

Table 2 Students in specialist pharmacological courses

Type of course

B.Sc. (Pharmacology)
B.Pharm.
Intercalated B.Sc.
Others

Total

$\begin{array}{r}\text { Numbers of } \\ 1971-72 \\ \text { (actual) } \\ 67 \\ 293 \\ 74 \\ 36 \\ \hline 470\end{array}$

Number of postgraduate degrees awarded during 1971

$$
\begin{array}{r}
24 \\
5 \\
71
\end{array}
$$

* Assuming $75 \%$ go on to practise pharmacy. * * Assuming all students go on to study medicine. 
on to the clinical part of their course. Nineteen specialist graduates went into a miscellaneous collection of jobs in hospitals, research councils and administration-the 'other units' of the future? The low unemployment rate (1\%) amongst these graduates is gratifying in comparison with the national unemployment rate $(3.8 \%)$ for graduates in 1970-71.

A more detailed analysis of the $\mathbf{4 1 3}$ graduates showed that 296 were from pharmacy schools, of whom $73 \%$ went to practise pharmacy in hospital or retail pharmacies. About $11 \%$ went into industry and $8 \%$ continued in academic courses. Of the remaining $117,70 \%$ continued in academic courses and $14 \%$ went into industry.

The disposition of 68 students who completed postgraduate courses in pharmacology in 1971 is given in Table 3 . Industry was their biggest single employer, taking about a quarter of that year's output. About $30 \%$ went into miscellaneous jobs in hospitals, research councils, administration, etc. and only two postgraduates went to practise pharmacy.

\section{Demand for pharmacologists}

This was assessed by asking all departments, as employers of pharmacologists, to give details of appointments to, and losses from, their staff and to provide information about proposed expansion of staff numbers.

The departments were asked to classify new appointments during 1970 and 1971 in terms of their most recent experience and type of employment rather than in terms of their qualifications. From the analysis in Table $4 \mathrm{~A}$, it appears that at least half of all appointees had been doing pharmacological work and only a few had been practising medicine. Those from fields less traditionally related to pharmacology (the bottom three rows of Table 4A) were employed more often by industrial rather than academic employers.
Table 4B shows that, whereas industry draws graduates equally from universities and industrial firms, academic departments draw from other academic institutions five times more than from industrial departments. A quarter of all appointees came directly from an academic course and for these it was perhaps their first job.

Table 5 shows that in these two years $(1970$ and 1971), about 36 of the pharmacologists leaving industrial and academic departments retired or went abroad. These have been considered absolute losses to a closed system, whereas losses to university and industrial departments and to technical colleges and other units may be considered as transfers both for appointments and for losses. Thus, these 36 losses over two years less the gain from abroad (7) represents a demand of 29 . The balance between appointments and losses (Table 6) shows a net gain for all sections of 117 in the two years considered. A maximum value for the demand during 1970 and 1971 may then be computed as the sum of the gain in academic and industrial departments and the other losses, i.e. $117+29=146$ or approximately 73 per annum.

In our computation of demand for pharmacologists at 73 jobs per annum, we have assumed that all the posts were filled by trained pharmacologists, but this is by no means certain. Some posts in pharmacology departments may still require a training in some other discipline, e.g. physiology or biochemistry. In 1970 and 1971, only $70 \%$ of academic and $46 \%$ of industrial established appointments went to people with experience in pharmacology and many of these were postgraduates whose first degree may not have been in pharmacology. This number of 73 is therefore a maximum estimate.

\section{Balance between production and demand}

We can assess this balance in two ways. Firstly, we can look at the unemployment rate of the

Table 3 Disposition of trained pharmacologists graduating in 1971

Specialist graduates Postgraduates

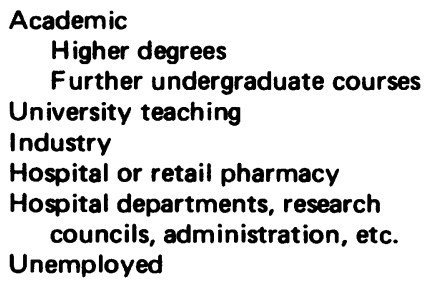

Total

\begin{tabular}{rr}
40 & 7 \\
69 & 5 \\
3 & 14 \\
47 & 18 \\
231 & 2 \\
19 & 21 \\
4 & 1 \\
\hline 413 & 68
\end{tabular}


specialist pharmacologists which is relatively low at $1 \%$, which implies that up to 1971 the supply of pharmacologists was not much in excess of demand.

Secondly, we can compare the production directly with the demand computed as above. From this we find that there were 481 specialist pharmacologists produced in 1971 (413 graduates and 68 postgraduates, Table 3 ), of whom 233 went into pharmacy and 121 into further academic courses, leaving 127 available for employment as pharmacologists. The computed demand from academic, industrial and other departments was, however, only 73 per year. There were therefore 54 pharmacologists in excess of demand, but only five of these were actually unemployed. After allowing for the errors inherent in these computations there must have been considerable employment of specialist pharmacologists in departments other than those which we surveyed. We do not know if the specialists are employed primarily as pharmacologists in these other jobs. For instance, positions in the quality control and medical sales or information departments in industry and in general administration, could be suitable for the specialists and may

Table 4 Appointments of graduate staff to academic and industrial departments during 1970 and 1971

(A)

In terms of recent experience in:

Pharmacology
Pharmacy
Medicine
Physiology
Biology or zoology
Biochemistry
Others

Total*

(B)

In terms of recent employment in: Undergraduate or postgraduate study

University, medical school and

hospital departments

Technical colleges

Industry

Research councils

Government

Others

From abroad

Total*
Academic

\section{Industrial}

\begin{tabular}{rr}
53 & 59 \\
3 & 6 \\
9 & 1 \\
11 & 3 \\
1 & 14 \\
11 & 16 \\
1 & 20 \\
\hline 89 & 119
\end{tabular}

\begin{tabular}{rr}
24 & 38 \\
52 & 29 \\
7 & 11 \\
10 & 26 \\
2 & 2 \\
0 & 0 \\
9 & 14 \\
3 & 4 \\
\hline 107 & 124
\end{tabular}

* From the information provided, the totals for sections A and B do not balance. The totals from section B have been used in further calculations.

Table 5 Losses of graduate staff from academic and industrial departments during 1970 and 1971
Academic departments and hospitals

Technical colleges

Industrial departments

Other departments

Abroad

Retirement, etc.

Total
Academic Industrial

\begin{tabular}{|c|c|}
\hline 12 & 11 \\
\hline 0 & 8 \\
\hline 9 & 24 \\
\hline 6 & 23 \\
\hline 3 & .7 \\
\hline 9 & 17 \\
\hline 39 & 90 \\
\hline
\end{tabular}


include some of the 65 students (Table 3) who went into industry.

This analysis shows that unless future surveys trace these other sources of demand we will have to rely on data provided by the teaching departments for an accurate estimate of the demand for recently graduated pharmacologists. However, the teaching departments cannot predict future demand, except in relation to their own expansion.

Our estimates of future demand are based on the proposed growth estimates provided by departments (see last section of Table 1) in which a total of 197 new jobs are to be created between 1972 and 1975, giving an average annual demand of about 66. If the losses outside our closed system remain as they were during 1970-71, then these will amount to another 29 vacancies each year during 1971-75. Thus an estimated maximum annual demand of $66+29=95$ pharmacologists may be predicted, an increase of $30 \%$ over the maximum annual demand (73) during 1970 and 1971.

This may be compared with the proposed doubling of B.Sc. (Pharmacology) graduates and the increases in other specialist graduates over the same period shown in Table 2. This table takes no account of any new specialist courses envisaged or of any increase in specialist output proposed since 1971. A new course started at Bristol in October, 1972, and courses are contemplated at Birmingham and Newcastle.

An estimate of the number of specialists likely to be seeking pharmacology jobs in 1975 is presented in the last column of Table 2 . We have assumed that all the intercalated B.Sc. students will return to medicine, and that $25 \%$ of those pharmacy students specializing in pharmacology will become available for jobs in pharmacology (on the basis of the 1971 figures described under 'Disposition'). Thus, in 1975 the discrepancy between the production of trained pharma-

Table 6 Appointments and losses* during 1970 and 1971

\begin{tabular}{|c|c|c|c|c|}
\hline & Appointments & Losses & Net gain & Gain/year \\
\hline Academic & 107 & 39 & 68 & 34 \\
\hline Industrial & 124 & 90 & 34 & 17 \\
\hline Other units & 17 & 2 & 15 & 7.5 \\
\hline & 248 & 131 & 117 & 58.5 \\
\hline
\end{tabular}

Vacancies in departments

Number \% of present staff

$\begin{array}{lrr}\text { Academic } & 15 & 4.5 \\ \text { Industrial } & 41 & 13.3\end{array}$

* Losses include losses from the profession.

Table 7 Qualifications of established staff

$\begin{array}{cccc} & \text { First degree in: } & \text { Number with } \\ \text { Medicine } & \text { Pharmacy } \quad \text { Science } \quad \text { Total higher degrees }\end{array}$

Academic departments*

\begin{tabular}{|c|c|c|c|c|c|}
\hline Medical schools & 65 & 41 & 75 & 181 & 145 \\
\hline University & 12 & 33 & 30 & 75 & 57 \\
\hline Non-university & 0 & 41 & 30 & 71 & 30 \\
\hline Industrial departments & 9 & 64 & 203 & 276 & 106 \\
\hline $\begin{array}{l}\text { Total } \\
\text { (\% of total) }\end{array}$ & $\begin{array}{c}86 \\
(14)\end{array}$ & $\begin{array}{l}179 \\
(30)\end{array}$ & $\begin{array}{l}338 \\
(56)\end{array}$ & $\begin{array}{c}603 \\
(100)\end{array}$ & $\begin{array}{l}338 \\
(56)\end{array}$ \\
\hline
\end{tabular}

*Data provided for only 327 of 348 academic staff members. 
cologists over the computed demand will be $286-98=188$; considerably greater than the excess of 54 in 1971 . Both the correction factors discussed earlier will apply to this prediction, i.e. that non-pharmacologists will be employed and that there is a demand which we cannot measure at present.

The 1964 survey concluded that the supply of, and demand for, pharmacologists were 'not very far out of balance' and up to 1971 this situation has been maintained. It now remains to be seen whether the increase in the reservoir of potential pharmacologists will disturb the balance of supply and demand in the future. If an excess of production does appear, we feel that the B.Sc. (Pharmacology) graduates might be particularly at risk, as the medical and pharmacy students can always return to their own profession.

\section{Organization of departments}

A more detailed analysis of the composition of the departments is possible from other data gathered in this survey.

\section{Qualifications}

The qualifications of all established pharmacologists were analysed (Table 7) on the basis of their first degree, according to certain arbitrary rules. Where there was more than one Bachelor's degree, a system was devised in which medical qualifications took precedence, followed by pharmacy and then science degrees. All B.Sc. degrees were classified as science degrees unless B.Sc. (Pharmacy) was stipulated, when it was included with the B.Pharm. under pharmacy qualifications. Thus it is possible that we have over-estimated the science graduates at the expense of the pharmacy graduates. A special group for B.Sc. (Pharmacology) was not included as this degree is of comparatively recent introduction. In academic departments generally, only about a quarter of the established staff were medically qualified. Of these, over $80 \%$ were in medical school departments, where they comprised $36 \%$ of the total staff (cf. $15 \%$ of the staff in non-medical university departments). Science qualifications $(40 \%)$ were more prevalent in medical school departments than pharmacy qualifications $(23 \%)$, but in the other departments, they were more equally distributed. Seventy per cent of all established staff had higher degrees (usually of doctorate status) and they were unevenly distributed ( $80 \%$ of the medical school staff; $40 \%$ of the non-university department staff).
In the $\mathrm{R} \& \mathrm{D}$ departments of industrial firms, there was a diversity of qualifications, the contribution of pharmacy and medical graduates being small, $23 \%$ and $3 \%$ respectively. The proportion with higher degrees (38\%) was also lower than the average for academic departments, though it was close to that in non-university departments.

Size and staff structure of academic departments

Academic pharmacology was divided almost equally between medical and non-medical schools in terms of departments, but to a lesser degree in terms of number of staff (Table 8). A large proportion of pharmacologists in academic departments are research staff and students (Table 8). Here, there is a marked disparity in distribution between non-university and university departments. The medical school departments have almost three-quarters of the total graduate research staff, and on average about twice as many per department as the other academic departments. The research students and visiting workers were more evenly distributed but the nonuniversity departments always had the least.

The structure of the established staff in the academic departments is shown in Table 9. In this survey, 24 out of the 27 medical school departments had a professor as head, 19 of whom had medical qualifications and 18 were external appointments. Of the 17 departments without prof essors, 11 were non-university departments. In the medical school departments, $23 \%$ of the staff were professors or readers whereas in the other departments the proportion is lower at $15 \%$ and $12 \%$ for the non-medical and non-university departments respectively. The proportion of professors to staff in medical school departments was similar to that in 1964, about $1: 6$. However, in the non-medical schools it has improved from 1 professor : 60 staff in 1964 to 1 professor : 9 staff in 1971. The average age of a professor was 49.8 years (43.3 at appointment) and that of readers and senior lecturers was 41.3 years.

\section{Technical and secretarial help (Table 10)}

Overall, industrial departments employed more technicians (666) than did academic departments (433). Industrial established staff also had more technicians per man than did their counterparts in academic departments. Although a significant proportion of technicians were graduates or of equivalent status (26\% in industrial, $16 \%$ in academic departments) enquiries revealed that few of these graduates had taken pharmacy or pharmacology degree courses. 


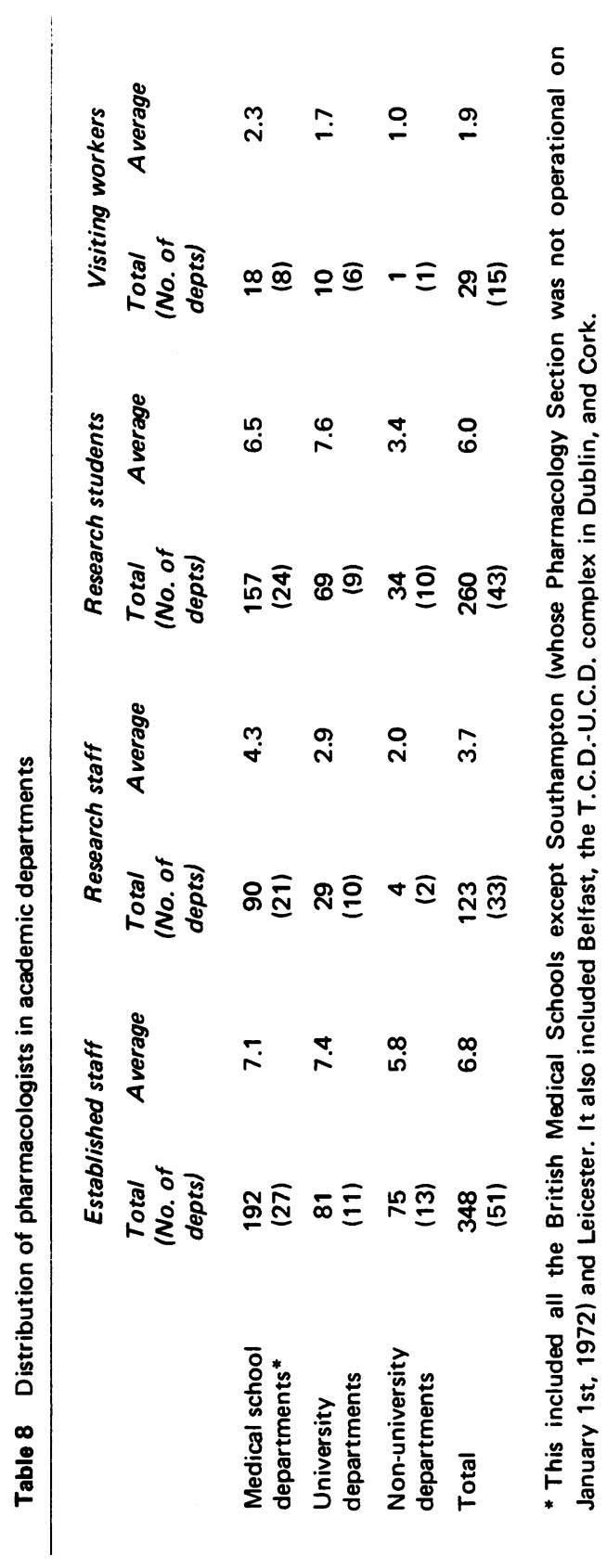

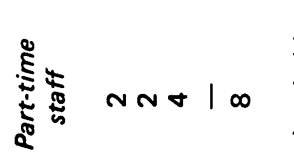

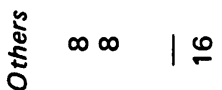

茍

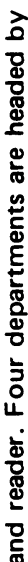

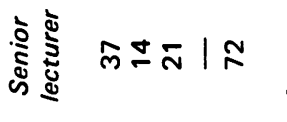

惫

ब.

ฐั๊ ำ

$\infty \mid \infty$

\)

มัก|

음

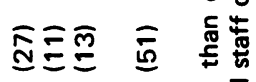

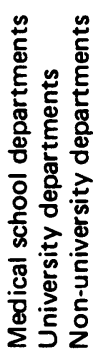

일 율

究

옹

ํㅗㄴ

空 
The secretarial/staff ratios were very similar for both academic and industrial departments at one secretary for every 4-5 staff members.

\section{Space in academic departments (Table 11)}

The term 'research space' includes staff offices, research laboratories and supporting facilities like electronic and mechanical workshops. Teaching space represents undergraduates' teaching space.

In terms of the total research space available, the average medical school department was between two to four times bigger than the other academic departments. Although there were relatively more research workers in medical schools, the average space per man was still double that available in university or non-university departments.

\section{Finance in academic departments}

Not every department answered the questions about the extent of their dependence on external funds for capital and running expenditure during the year 1970-71, but the answers that were provided have been summarized in Table 12. Most departments, especially non-university departments, received the majority of funds from internal sources for both forms of expenditure.

Finance for research covers both research staff

Table 10 Technical and secretarial assistance

\begin{tabular}{lccccccc} 
& \multicolumn{3}{c}{ Technicians } & \multicolumn{3}{c}{ Secretaries } \\
& $\begin{array}{c}\text { Graduates and } \\
\text { graduate equiv. }\end{array}$ & Others & $\begin{array}{c}\text { Technician/staff* } \\
\text { ratio }\end{array}$ & Full-time & Part-time & $\begin{array}{c}\text { Secretary/staff* } \\
\text { ratio }\end{array}$ \\
Academic & & & 367 & 1.24 & 59 & 27 & 0.21 \\
Industrial* * & 172 & 494 & 2.4 & 63 & 0 & 0.23
\end{tabular}

* Staff here refers to established staff only. * Industrial here refers to pharmacology R \& D departments only.

Table 11 Research and teaching space (in square feet)

\begin{tabular}{lcccc} 
& \multicolumn{2}{c}{ Research * } & \multicolumn{2}{c}{ Teaching } \\
& $\begin{array}{c}\text { Average total area } \\
\text { (range) }\end{array}$ & $\begin{array}{c}\text { Area per research } \\
\text { worker * }\end{array}$ & $\begin{array}{c}\text { Average total area } \\
\text { (range) }\end{array}$ & $\begin{array}{c}\text { Student density } \\
\text { no./1000 sq. ft. }\end{array}$ \\
$\begin{array}{l}\text { Medical school } \\
\text { departments }\end{array}$ & $\begin{array}{c}8,200 \\
(1,200-20,000)\end{array}$ & 482 & $\begin{array}{l}3,500 \\
(600-6,700)\end{array}$ & 34 \\
$\begin{array}{l}\text { University } \\
\text { departments }\end{array}$ & $\begin{array}{c}4,300 \\
(1,500-5,800)\end{array}$ & 253 & $\begin{array}{c}2,700 \\
(1,800-5,800)\end{array}$ & 17.5 \\
$\begin{array}{l}\text { Non-university } \\
\text { departments }\end{array}$ & 2,000 & & 2,400 & 12.5
\end{tabular}

* Research space includes staff laboratories, offices, preparation rooms and workshops. * Research workers here include established staff, research staff, postgraduate students and visitors.

Table 12 Financial support in academic departments

\begin{tabular}{lcccccc} 
& \multicolumn{3}{c}{ Capital expenditure } & \multicolumn{3}{c}{ Running expenditure } \\
& $\begin{array}{l}\text { More } \\
\text { internal }\end{array}$ & Equal & $\begin{array}{c}\text { More } \\
\text { external }\end{array}$ & $\begin{array}{c}\text { More } \\
\text { internal }\end{array}$ & Equal & $\begin{array}{c}\text { More } \\
\text { external }\end{array}$ \\
Medical school departments & 9 & 4 & 5 & 14 & 3 & 2 \\
University departments & 3 & 1 & 3 & 4 & 1 & 2 \\
Non-university departments & 9 & 1 & 0 & 12 & 1 & 1 \\
& 21 & 6 & 8 & 30 & 5 & 5
\end{tabular}


and students (Table 13). The majority of the graduate research staff were supported by either the research councils $(40 \%)$ or other funds $(35 \%)$. The latter category includes private foundations, charities and foreign Government grants. Support for research students varied with the type of department. Thus, in non-university departments, $60 \%$ of the students were supported by internal funds, whereas in universities and medical schools only $16 \%$ and $13 \%$ respectively were supported by internal funds and the research councils supported nearly half of their research students.

\section{Pharmacology teaching}

Nearly 5,000 undergraduates (Table 14) were taught pharmacology in 51 academic departments. For medical students, the course took up about $100 \mathrm{~h}$ on average (range 50-196 hours). Pharmacy students received more pharmacology on average with $390 \mathrm{~h}$, veterinary students $105 \mathrm{~h}$, but dentistry students had only $31 \mathrm{~h}$ teaching. The average duration of the specialist courses ranges from 1.3 years for the B.Sc. (Pharmacology) to 0.9 years for intercalated courses and 0.7 years for the pharmacy student specializing in pharmacology. The numbers of students taking the specialist courses have been given in Table 2 .

Teaching was carried out by the established staff (348) supplemented by an equal number of part-time assistants, e.g. research workers and students, members of other departments and so on. The average staff-student ratio would be about 1 to 7 , but we feel the wide variation in the precise teaching load at schools teaching pharmacology at different levels to different students makes such calculations not very helpful.

The average area available for teaching purposes varied between the different types of academic department but medical schools included both the smallest, 600 sq. $\mathrm{ft}$., and the largest, 6,700 sq. $\mathrm{ft}$., teaching areas (Table 11). Medical schools had an average student density between two and three times higher than that of other academic depart-

Table 13 Financial support for research staff in academic departments (including graduate students and visitors, but excluding established staff)

Internal
funds Industry $\begin{gathered}\text { Research } \\ \text { council Other }\end{gathered}$

(1) Graduate research staff Medical school departments University departments Non-university departments Total

$\begin{array}{r}11 \\ 2 \\ 3 \\ \hline 16\end{array}$

$\begin{array}{r}8 \\ 2 \\ 0 \\ \hline 10\end{array}$

\begin{tabular}{|c|}
\hline 34 \\
\hline 8 \\
\hline 0 \\
\hline 42 \\
\hline
\end{tabular}

(2) Graduate students Medical school departments University departments Non-university departments

\begin{tabular}{ll}
21 & 10 \\
11 & 10 \\
20 & 3 \\
\hline 52 & 23
\end{tabular}

Total

10
10
3
$\frac{23}{23}$

\begin{tabular}{rrr}
80 & 43 \\
29 & 17 \\
4 & 6 \\
\hline 113 & & 66
\end{tabular}

(3) Visiting workers Medical school departments University departments Non-university departments Total

\begin{tabular}{rrrr}
0 & 0 & 0 & 11 \\
0 & 1 & 0 & 9 \\
1 & 0 & 0 & 0 \\
\hline 1 & 1 & $\frac{1}{20}$
\end{tabular}

Table 14 Number of students taught pharmacology and duration of their courses

$\begin{array}{lcccccc} & \text { Medicine } & \text { Pharmacy } & \text { Dentistry } & \begin{array}{c}\text { Veterinary } \\ \text { science }\end{array} & \begin{array}{c}\text { Biological } \\ \text { science }\end{array} & \text { Total } \\ & 2,875 & 516 & 704 & 325 & 495 & 4,915 \\ \begin{array}{l}\text { Number } \\ \begin{array}{l}\text { Course duration } \\ \text { (hours) }\end{array}\end{array} & 112 & 390 & 31 & 105 & 169 & \\ \text { (Range) } & (50-196) & (80-630) & (5-70) & (70-144) & (20-450) & \end{array}$




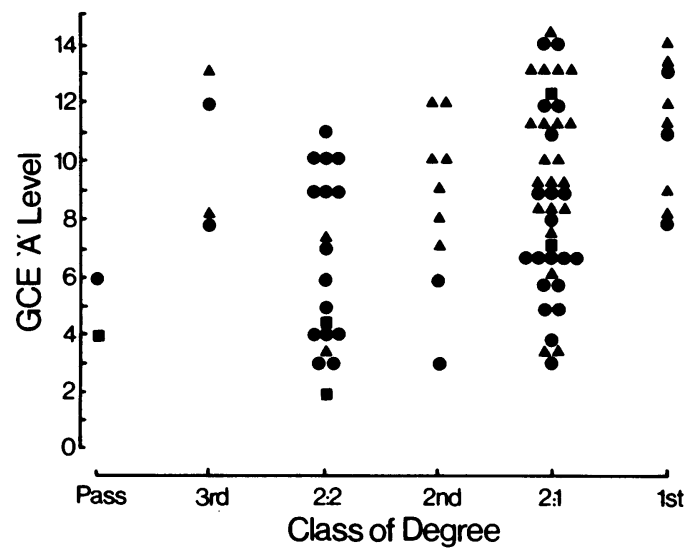

Fig. 1 Correlation of student performance in the General Certificate of Education Advanced Level examination (GCE ' $A$ ' level) with the class of degree they obtained in 1971. Results are plotted for students graduating with a B.Sc. in Pharmacology ( $\Delta)$, B.Pharm. or B.Sc. Pharmacy (๑) or M.I. Biol. (ø). A numerical equivalent of ' $A$ ' level achievement was obtained by making grade $A=5, B=4, C=3, D=2$, and $E=1$.

ments. These student densities must be interpreted in relation to the duration of the various courses taught.

Industrial $\mathrm{R}$ \& $\mathrm{D}$ departments themselves contributed to the training of pharmacologists in three ways: sandwich course and vacation students were widely accepted (39 students per year in 22 departments), 50 members of staff were enrolled for higher degrees; and 12 departments organized their own training courses for graduate staff.

\section{Survey of recent graduates}

In this survey, with the co-operation of departments from each of the academic sub-categories, a questionnaire was sent to the last known address of students specializing in pharmacology, who had graduated in 1971. Of the 410 forms sent out, only 94 were returned and the results of this small sample are given below.

The age, distribution and sex of these students is given in Table 15 which also shows the sex ratio of graduate pharmacologists (data taken from the main survey). It can be seen that while women formed $31 \%$ of the undergraduate population they only provided 13 and $24 \%$ of established academic and industrial staff.

An analysis of the quality of students attracted into pharmacology and how their degree correlated with G.C.E. advanced (A) level performance is given in Figure 1. Approximately $50 \%$ of the 
students who completed the forms started with $3 \mathrm{C}$ grades, or better, at ' $A$ ' level. It is perhaps worthwhile to note that no student who obtained a first-class degree entered university with much less than three grade C's at ' $A$ ' level but $44 \%$ of those with an upper second had ' $A$ ' levels inferior to this even down to three ' $E$ ' grades.

Table 16 presents information on the disposition of the graduates. The proportion of $75 \%$ for pharmacy students who went into pharmacy may be compared with the figure of $73 \%$ which we obtained from a larger sample of pharmacy students (see Table 3 ). Some $27 \%$ of the graduates were accepted for postgraduate courses, most having taken a B.Sc.-type specialist degree. Industry provided $12 \%$ of graduates with their employment. Only one respondent was unemployed though it might be argued that the unemployed graduates are less likely to fill out questionnaires on the employment of pharma- cologists. However, the unemployment rate in this small sample is the same as that of the larger sample provided in Table 3 .

The reaction of students and employers to the teaching is dealt with in the next few tables. The courses were, on the whole, moderately satisfying and interesting, and for those who were actually doing pharmacological work they seemed to be fairly effective in providing technical training (Table 17). A considerable proportion felt that autonomic and peripheral nervous system pharmacology was over-emphasized. The most frequent criticism was the lack of teaching on the clinical use of drugs (Table 18). Also, the coverage of biochemistry and particularly of mathematics and statistics was not adequate for a significant number of students (lower half of Table 18). This complaint was echoed by the industrial employers who (Table 19, data taken from main survey) also commented on the weakness in statistics of both

Table 16 Training and present occupation of recent pharmacology graduates

\begin{tabular}{lcccc}
\hline \multicolumn{1}{c}{ Present occupation } & \multicolumn{4}{c}{ Type of pharmacology course taken } \\
Undergraduate (all in medical courses) & 14 & 2 & 0 & 16 \\
Postgraduate & 16 & 8 & 1 & 25 \\
Industrial R \& D & 7 & 0 & 4 & 11 \\
Teaching & 2 & 0 & 0 & 2 \\
Government/research councils & 1 & 1 & 2 & 4 \\
Hospital or retail pharmacy & 0 & 33 & 1 & 34 \\
Administration & 1 & 0 & 0 & 1 \\
Total & -11 & -44 & -8 & 93
\end{tabular}

Table 17 General reactions of graduates to pharmacology course

(a) How did your course in pharmacology measure up to your expectations?

$\begin{array}{lc} & \% \\ \text { Completely satisfied } & 36 \\ \text { Fairly satisfied } & 61 \\ \text { Dissatisfied } & 3 \\ \text { Interesting } & 84 \\ \text { Too specialized } & 23.5\end{array}$

(b) If your present occupation requires some pharmacology training, how did your course fit you for it?

$\begin{array}{ll} & \% \\ \text { Very well fitted } & 29 \\ \text { Fairly well fitted } & 55 \\ \text { Badly fitted } & 16\end{array}$


Table 18 Graduates' reactions to components of pharmacology course

\begin{tabular}{lccc}
\multicolumn{1}{c}{ Subject } & $\begin{array}{c}\% \\
\text { Satisfactory }\end{array}$ & $\begin{array}{c}\% \\
\text { Overemphasized }\end{array}$ & $\begin{array}{c}\% \text { Underemphasized } \\
\text { Pharmacokinetics }\end{array}$ \\
Autonomic and peripheral nervous system & 58.5 & 5.5 & 36 \\
C.N.S. & 68 & 28 & 4 \\
Cardiovascular system & 61 & 14.5 & 24.5 \\
Reproductive and endocrine pharmacology & 70.5 & 5 & 24.5 \\
Renal pharmacology & 61 & 4 & 35 \\
Gastrointestinal pharmacology & 66.5 & - & 33.5 \\
Clinical use of drugs & 49.5 & - & 50.5 \\
Toxicology & 16 & - & 84 \\
& 40.5 & - & 59.5 \\
Coverage of & Satisfactory & Excessive & Inadequate \\
Bhysiology & 91.5 & 1 & 7.5 \\
Maths and statistics & 56 & 8 & 36
\end{tabular}

Table 19 Industrial employers' reaction to training of pharmacologists

\begin{tabular}{|c|c|c|}
\hline \multirow[b]{2}{*}{ Aspect of training } & \multicolumn{2}{|c|}{$\%$ of employers satisfied } \\
\hline & $\begin{array}{l}\text { Graduate } \\
\text { course }\end{array}$ & $\begin{array}{c}\text { Postgraduate } \\
\text { course }\end{array}$ \\
\hline Pharmacology & 89 & 93 \\
\hline Physiology & 65 & 65 \\
\hline $\begin{array}{l}\text { Chemistry and } \\
\text { biochemistry }\end{array}$ & 56 & 54 \\
\hline Statistics & 27 & 39 \\
\hline $\begin{array}{l}\text { Experimental design } \\
\text { and technique }\end{array}$ & 40 & 79 \\
\hline $\begin{array}{l}\text { Ability to work } \\
\text { without supervision }\end{array}$ & 40 & 79 \\
\hline $\begin{array}{l}\text { Orientation to working } \\
\text { in industry }\end{array}$ & 69 & 80 \\
\hline $\begin{array}{l}\text { Ability to write reports } \\
\text { and use English }\end{array}$ & 25 & 56 \\
\hline
\end{tabular}

graduate and postgraduate pharmacologists. From the industrial employer's point of view, postgraduate courses improved students, as they were

\section{References}

BAKHLE, Y.S. \& PATON, W.D.M. (1966). Report on the questionnaire on the organization of pharmacology in Great Britain. Br. J. Pharmac. Chemother., 27, 239-248. better in most aspects, particularly in statistics and general literacy. Perhaps the effort of writing a thesis has some real benefit for the student. However, there was little support $(22 \%)$ from industry for the idea of more one year postgraduate courses in pharmacology, although $80 \%$ of the toxicology units thought an M.Sc. course in toxicology would be useful.

Although the number of graduates replying was small, we can take some comfort from the finding that the pharmacology courses are interesting to the students and provide technical training which both graduate and employer find adequate. From the high entry into postgraduate courses pharmacology graduates are suitably qualified for academic research.

The deficiencies in the teaching of mathematics, statistics and the clinical use of drugs deserve attention as they have important implications for basic and applied pharmacology.

We are grateful to our pharmacologist colleagues for advice in designing the questions and for their help in completing them. We are indebted to our secretarial staff and in particular, Miss Anna Curtis, for their unstinting efforts.
SMITH, R.N. (1974). Clinical pharmacology in the United Kingdom. Clin. Pharmac. Ther. (in press).

(Received A ugust 29, 1973) 